\title{
Pengaruh Aspek Arsitektur dan Perencanaan Kota Terhadap Ter- bentuknya Ikatan Batin Dengan Suatu Tempat (Place attachment)
}

\author{
Jenny Ernawati ${ }^{1}$ \\ 1 Universitas Brawijaya/Fakultas Teknik \\ Alamat Email penulis : jny23ern@gmail.com
}

\begin{abstract}
ABSTRAK
Penelitian ini dimaksudkan untuk mengetahui pengaruh kualitas aspek arsitektur dan perencanaan kota pada suatu lingkungan hunian terhadap terbentuknya place attachment (ikatan batin atau kelekatan psikologis seseorang terhadap suatu tempat atau lingkungan huniannya). Aspek arsitektur dan perencanaan kota dioperasionalkan melalui persepsi penghuni terhadap kualitas arsitektur dan perencanaan kota di lingkungan huniannya. Penelitian ini menggunakan metode survei yang terdiri dari dua tahap. Survei tahap pertama melibatkan 40 responden yang dipilih secara acak untuk menggali variabel arsitektur dan perencanaan kota menggunakan kuesioner dengan kombinasi pertanyaan terbuka dan tertutup. Survei tahap pertama menghasilkan 28 variabel arsitektur dan perencanaan kota yang kemudian digunakan dalam survei tahap kedua yang dimaksudkan untuk menggali persepsi masyarakat terhadap kualitas arsitektur dan perencanaan kota. Pada survei tahap kedua ini digunakan self-administered kuesioner dengan menggunakan skala Likert dengan tujuh skala untuk mengevaluasi kualitas arsitektur dan urban planning (28 variabel) dan skala unidimensional untuk mengukur place attachment ( 5 variabel). Seratus sembilan puluh tiga responden yang dipilih secara acak dari lima kecamatan di Kota Malang berpartisipasi dalam penelitian ini. Analisis faktor dan analisis regresi digunakan untuk menggali pengaruh aspek arsitektur dan perencanaan kota terhadap place attachment. Hasil penelitian menunjukkan ada empat faktor arsitektur dan perencanaan kota yang signifikan mempengaruhi terbentuknya place attachment, yaitu Estetika Bangunan dan Lingkungan, Fasilitas Pejalan Kaki, Organisasi Jaringan Jalan, dan Ketersediaan Ruang Terbuka Hijau. Secara keseluruhan, keempat faktor fisik tersebut memberikan kontribusi $27.2 \%$ terhadap terbentuknya place attachment.
\end{abstract}

Kata kunci: Place attachment, Persepsi Masyarakat, Arsitektur, Perencanaan Kota.

\begin{abstract}
This paper reports an empirical study that was aimed to explore community's evaluations of architecture and urban planning qualities and it's influence on place attachment. Place attachment is understood as emotional or affective connection that people develop with their places of residence, due to the meaning given to that site. This study used a survey research design which was conducted in two stages. The first stage of the surveys was to explore variables of architecture and town planning qualities using a combination of open-and-close-ended questions. Forty respondents selected randomly to participate in this phase of study. This resulted 28 variables of architecture and urban planning qualities, which were then used for the next stage of the survey. The second stage of the survey used questionnaire involving seven-point Likert scale to evaluate those qualities and unidimensional scale of place attachment consisted of five variables. There were 193 respondents from five different neighbourhoods in Malang chosen randomly to participate in the survey. Several multivariate data analysis, including factor analysis and re-
\end{abstract}


gression analysis were used to explore effects of architecture and urban planning qualities on place attachment. Results indicated that, in general, perceived architecture and urban planning qualities are significant as predictors of place attachment. These predictors consist of four factors that are Built Environmental Aesthetics; Pedestrian Facilities; Street Network; and Green Open Space Availability. Those four factors influence $27.2 \%$ of the development of place attachment.

Keywords: place attachment; community's evaluations; architecture; urban planning and design

\section{Pendahuluan}

Kepuasan terhadap lingkungan hunian dan kelekatan serta kecintaan seseorang terhadap suatu tempat atau lingkungan huniannya (place attachment) merupakan konsep penting dalam Psikologi Lingkungan (Tognoli, 1987; Altman \& Low, 1992; Sundstrom et al., 1996; Bonaiuto et al., 1999). Kedua konsep tersebut digunakan sebagai dasar teoritis dan dasar penelitian empiris untuk menjelaskan hubungan antara manusia dengan lingkungan hunian mereka, baik dalam lingkup rumah, lingkungan hunian (neighborhood), maupun kota (Bonaiuto et al., 1999).

Place attachment pada dasarnya mengacu pada terbentuknya ikatan batin seseorang dengan suatu tempat, misalnya lingkungan hunian. Ikatan batin yang merupakan kelekatan dan kecintaan terhadap lingkungan hunian secara positif akan memberikan rasa aman, nyaman, tentram, yang pada gilirannya akan mermberikan kesejahteraan dan kebahagiaan bagi masyarakat dalam menjalankan kehidupannya (Ernawati, 1992). Sebaliknya, tidak adanya ikatan batin tersebut (place attachment) dapat menimbulkan rasa "terasing" dari lingkungannya, rasa tidak betah/ tidak kerasan di lingkungannya, yang pada gilirannya akan memberikan dampak buruk secara psikologis pada masyarakat penghuni. Apabila kondisi seperti ini berlangsung terus menerus dapat menimbulkan tekanan mental yang berdampak buruk bagi kesejahteraan hidup manusia.Oleh karena itu perlu dikaji faktor-faktor yang berpengaruh terhadap pembentukan ikatan batin atau kelekatan dan kecintaan terhadap lingkungan hunian.

Dari kajian pustaka yang telah dilakukan, secara teoritis salah satu faktor penentuplace attachment adalah kepuasan berhuni di suatu tempat (Bonaiuto et al., 1999; Bonaiuto et al., 2004; Bonnes et al., 1997; Bonnes et al., 2004).Kepuasan berhuni muncul karena persepsi positif penghuni terhadap kualitas lingkungan huniannya.Oleh karena itu, hubungan antara kepuasan berhuni yang dijembatani oleh persepsi terhadap kualitas lingkungan hunian dengan place attachment merupakan persoalan mendasar dalam bidang ilmu psikologi lingkungan.

Sayangnya hubungan kedua konsep tersebut masih sangat jarang dikaji (Bonaiuto et al., 1999). Dan dari penelitian yang jumlahnya masih sangat sedikit tersebut kebanyakan dilakukan di negara Barat (misal Bonaiuto et al., 1999; Bonaiuto et al., 2004; Bonnes et al., 1997; Bonnes et al., 2004), sedangkan di Indonesia masih belum dilakukan. Di Indonesia studi-studi tentang kepuasan berhuni lebih mengarah pada hunian secara mikro seperti kajian kepuasan penghuni terhadap aspek fisik di perumahan tertentu (misal Kwanda et al., 2001), pada tipe rumah tertentu di kawasan perumahan tertentu (misal Rahardjo \& Wibowo, 2003), ataupun kepuasan penghuni pada hunian rumah susun (misal Prasojo, W. \& Frida, N., 2014).Sedangkan penelitian yang mendasar untuk melihat hubungan konsep kepuasan berhuni dan place attachment yang dapat berlaku secara umum belum pernah dilakukan.Oleh karena itu, penelitian ini dimaksudkan untuk mengisi kekosongan tersebut.

Berdasarkan kajian pustaka yang dilakukan, kualitas lingkungan hunian dapat ditinjau dari 4 aspek, yaitu aspek arsitektur dan perencanaan kota, aspek hubungan sosial, aspek pelayanan masyarakat, dan aspek tautan lokal atau kontekstual (Bonaito et al., 1999; Bonaiuto et al., 2004; Bonnes et el., 1997; Bonnes et al., 2004). Dari keempat aspek tesebut, aspek arsi- 
tektur dan perencanaan kota merupakan aspek fisik spasial yang penting dalam menentukan kualitas suatu lingkungan hunian. Oleh karena itu, tulisan yang merupakan satu bagian dari serangkaian penelitian yang dilakukan ini difokuskan pada pengaruh aspek arsitektur dan perencanaan kota pada place attachment (ikatan batin masyarakat dengan lingkungan huniannya). Temuan dalam penelitian ini diharapkan dapat menjelaskan pola hubungan kedua konsep tersebut dengan mengungkap faktor-faktor dominan dalam aspek arsitektur dan perencanaan kota yang dapat memprediksi terbentuknya ikatan batin masyarakat dengan lingkungan huniannya (place attachment).

Lebih jauh hubungan antara kepuasan terhadap aspek arsitektur dan perencanaan kota dalam suatu lingkungan hunian dengan place attachment ini diharapkan dapat memberikan kontribusi yang sangat mendasar dan bermanfaat sebagai dasar teoritik bagi bidang ilmu yang banyak mengkaji hubungan manusia dan lingkungan seperti arsitektur maupun perencanaan dan perancangan kota.

\section{Bahan dan Metode}

Penelitian ini dilakukan dengan menggunakan pendekatan kualitatif dan kuantitatif. Pendekatan kualitatif dilakukan untuk menggali variabel kualitas lingkungan hunian dari aspek arsitektur dan perencanaan kota. Selanjutnya pendekatan kuantitatif dilakukan untuk menggali persepsi dan evaluasi masyarakat terhadap kualitas aspek arsitektur dan perencanaan kota dan place attachment (ikatan batin masyarakat dengan lingkungan huniannya) dengan menggunakan teknik pengukuran skala Likert.

Penelitian ini merupakan penelitian deskriptif (menjelaskan gejala/fenomena) dan penelitian korelasional (mengkaji hubungan antara dua konsep) dengan metode penelitian survei. Penelitian ini dilakukan di Kota Malang, yang merupakan kota kedua terbesar di Jawa Timur setelah Surabaya. Pengaruh aspek arsitektur dan perencanaan kota pada lingkungan hunian terhadap terbentuknya place attachment yang merupakan hasil penelitian ini diharapkan dapat digeneralisir di lingkungan-lingkungan hunian yang lain.

\subsection{Metode Pengumpulan Data}

\subsubsection{Metode Pemilihan Sampel}

Populasi dalam penelitian ini adalah seluruh masyarakat Kota Malang yang menjadi pelanggan telepon, yaitu sejumlah 111.846 jiwa (Sumber: Data pelanggan telepon Kota Malang tahun 2008), dengan asumsi daftar nama kepala keluarga di seluruh wilayah kota tercantum dalam buku telpon. Agar hasil penelitian ini dapat digeneralisir, maka pemilihan sampel menggunakan metode simple random sampling (lihat Huck, 2000; Hoyle et al., 2002). Jumlah responden yang dipilih ada 240 orang (memenuhi sekitar 6,5\% tingkat kesalahan atau dengan tingkat keyakinan 93,5\%) yang dipilih secara acak dari buku telepon terbaru dengan bantuan perangkat research randomizer (www.randomizer.org). Selanjutnya dipilih 40 responden secara acak dari 240 sampel terpilih sebagai responden survei tahap satu dengan tujuan untuk menggali variabel aspek arsitektur dan perencanaan kota pada lingkungan hunian menurut pendapat masyarakat. Sisa responden sebanyak 200 sampel digunakan untuk survei pada tahap dua yang bertujuan untuk menggali persepsi dan evaluasi masyarakat terhadap kualitas aspek arsitektur dan perencanaan kota pada lingkungan huniannya dan ikatan batin masyarakat dengan lingkungan huniannya (place attachment). Dari 200 responden yang terpilih (yang tersebar di lima kecamatan di Kota Malang), hanya 
193 orang yang mengisi kuesioner. Tujuh kuesioner tidak terisi karena responden tidak ada di tempat atau telah pindah tempat tinggal.

\subsubsection{Instrumen Penelitian dan Variabel Penelitian}

Instrumen yang digunakan dalam penelitian ini adalah self administered questionnaire, yaitu kuesioner yang dapat diisi sendiri oleh responden. Untuk menentukan variabel aspek arsitektur dan perencanaan kota suatu lingkungan hunian, maka dilakukan survei menggunakan kuesioner dengan pertanyaan semi tertutup untuk menggali pendapat masyarakat terhadap variabel aspek arsitektur dan perencanaan kota suatu lingkungan hunian secara kualitatif. Responden diminta untuk memilih variabel apa yang menurut mereka penting sebagai aspek arsitektur dan perencanaan kota dalam menentukan kepuasan terhadap lingkungan hunian mereka serta menambahkan jawaban tertulis selain jawaban pada pilihan.

Aspek arsitektur dan perencanaan kota suatu lingkungan hunian yang berkualitas dikembangkan dari tiga variabel utama yaitu ruang arsitektur dan perencanaan kota; organisasi aksesibilitas dan jalan; dan tata hijau (Bonaiuto et al., 1999; Bonaiuto et al., 2004; Bonnes et al., 1997; Bonnes et al., 2004). Dari hasil survei kualitatif diperoleh ada 28 variabel aspek arsitektur dan perencanaan kota yang menurut pendapat masyarakat menentukan kualitas lingkungan hunian. Keduapuluh delapan variabel tersebut adalah:

Tabel 1. Variabel Kualitas Aspek Arsitektur dan Perencanaan Kota

\begin{tabular}{|c|c|c|}
\hline SUB ASPEK/KONSEP & \multicolumn{2}{|c|}{ VARIABEL } \\
\hline \multirow{11}{*}{$\begin{array}{l}\text { Ruang Arsitektur \& } \\
\text { Perencanaan Kota }\end{array}$} & 1. & Gaya Bangunan \\
\hline & 2. & Warna Bangunan \\
\hline & 3. & Bentuk Bangunan \\
\hline & 4. & Keindahan Bangunan \\
\hline & 5. & Arsitektur Lingkungan \\
\hline & 6. & Keseimbangan jumlah bangunan dgn Ruang Terbuka \\
\hline & 7. & Ukuran Bangunan \\
\hline & 8. & Ketinggian Bangunan \\
\hline & 9. & Kualitas Bangunan \\
\hline & 10. & Kepadatan Jumlah Bangunan \\
\hline & 11. & Konstruksi Bangunan \\
\hline \multirow{7}{*}{$\begin{array}{l}\text { Organisasi \& Jaringan } \\
\text { Jalan }\end{array}$} & 1. & Lebar Jalan \\
\hline & 2. & Kemudahan Sirkulasi \\
\hline & 3. & Kenyamanan untuk orang berkebutuhan Khusus \\
\hline & 4. & Ketersediaan Tempat Parkir \\
\hline & 5. & Kemudahan Pencapaian ke Pusat Kota \\
\hline & 6. & Hub. Tempat Tinggal dgn lokasi-lokasi penting kota \\
\hline & 7. & Kemudahan menuju luar kota \\
\hline
\end{tabular}




\begin{tabular}{|c|c|c|}
\hline \multirow[t]{6}{*}{ SUB ASPEK/KONSEP } & \multicolumn{2}{|c|}{ VARIABEL } \\
\hline & 8. & Desain Jaringan Jalan \\
\hline & 9. & Dampak keberadaan jalan raya terhadap hunian \\
\hline & 10. & Lebar trotoar \\
\hline & 11. & Perbandingan jumlah pengendara dengan pejalan kaki \\
\hline & 12. & Kemudahan bagi pejalan kaki \\
\hline \multirow[t]{5}{*}{ Tata Hijau } & 1. & Jumlah Area Hijau \\
\hline & 2. & Jarak lokasi taman dari hunian \\
\hline & 3. & Keberadaan ruang hijau yang dapat dimanfaatkan untuk santai atau bersosialisasi \\
\hline & 4. & Jumlah pohon \\
\hline & 5. & Kondisi area hijau \\
\hline
\end{tabular}

Selanjutnya variabel tersebut digunakan dalam kuesioner pada survei terhadap 200 responden untuk menggali persepsi dan evaluasi masyarakat perkotaan terhadap kualitas aspek arsitektur dan perencanaan kota pada lingkungan huniannya.

Kepuasan terhadap aspek arsitektur dan perencanaan kota yang terdiri dari 28 variabel tersebut diukur dengan menggunakan skala Likert yang terdiri dari 7 skala, dari "sangat tidak setuju" hingga "sangat setuju". Responden hanya diminta untuk melingkari salah satu angka dari skala tersebut untuk setiap pertanyaan yang sesuai dengan pendapat mereka di antara angka 1 (sangat tidak setuju) sampai dengan angka 7 (sangat setuju).

Bagian terakhir kuesioner mengukur place attachment, yaitu ikatan batin atau kelekatan psikologis antara individu dengan lingkungan huniannya. Pengukuran konsep ini juga menggunakan skala Likert yang terdiri dari 7 skala, dari "sangat tidak setuju" (nilai=1) hingga "sangat setuju" (nilai=7). Responden diminta menilai lima pertanyaan (variabel) place attachment (Bonaiuto et al., 1999; Bonnes et al., 1997, Ernawati \& Mustikawati, 2010). Kelima pertanyaan ini diajukan untuk mengungkap perasaan positif atau kecintaan penghuni terhadap lingkungan huniannya; keinginan mereka untuk tidak pindah dari lingkungannya saat ini; dan relevansi tempat hunian bagi identitas seseorang. Secara keseluruhan kelima pertanyaan mengenai place attachment (ikatan batin masyarakat dengan lingkungan hunian mereka) dapat dilihat pada Tabel 2.

Tabel 2. Variabel Place attachment

\begin{tabular}{|l|l|}
\hline \multirow{3}{*}{$\begin{array}{l}\text { KONSEP } \\
\text { Place attachment }\end{array}$} & $\begin{array}{l}\text { VARIABEL } \\
\text { Lingkungan hunian merupakan tempat tinggal ideal }\end{array}$ \\
\cline { 2 - 3 } & Lingkungan hunian sudah menjadi bagian dari hidup \\
\cline { 2 - 3 } & Terdapat keterikatan emosional dengan lingkungan hunian \\
\cline { 2 - 3 } & $\begin{array}{l}\text { Perasaan berat untuk meninggalkan lingkungan hunian } \\
\text { Perasaan senang untuk tinggal di lingkungan hunian }\end{array}$ \\
\hline
\end{tabular}

(Sumber: diolah dari Bonaiuto et al., 1999; Bonaiuto et al., 2004; Bonnes et al., 1997; Bonnes et al., 2004) 
Pelaksanaan penelitian ini dilakukan dalam dua tahap. Tahap pertama dilakukan untuk menggali variabel aspek arsitektur dan perencanaan kota pada suatu lingkungan hunian. Kuesioner diberikan kepada 40 responden.Berdasarkan jawaban responden pada survei tahap satu, disusun kuesioner untuk survei tahap dua.

Survei tahap dua bertujuan untuk menggali penilaian kualitas aspek arsitektur dan perencanaan kota pada lingkungan hunian dan mengevaluasi place attachment (ikatan batin yang mereka rasakan terhadap lingkungan hunian). Sebanyak 200 responden dipilih secara acak dengan menggunakan alat bantu research randomizer. Dari 200 responden terpilih, hanya 193 responden yang mengisi kuesioner.Tujuh responden tidak mengikuti tahap ini karena ternyata responden tidak ada di tempat atau telah pindah tempat tinggal.

Pada survei tahap dua ini responden diminta untuk menilai kualitas aspek arsitektur dan perencanaan kota pada lingkungan huniannya dan mengevaluasi ikatan batin yang mereka rasakan terhadap lingkungan hunian tersebut. Penilaian kualitas aspek arsitektur dan perencanaan kota dilakukan terhadap 28 point pertanyaan yang merupakan variabel kualitas aspek arsitektur dan perencanaan kota pada lingkungan hunian sebagai hasil survei tahap satu dan lima variabell place attachment (ikatan batin terhadap lingkungan hunian) dengan menggunakan skala Likert.

Kuesioner ditinggalkan selama tiga hari agar responden dapat mengisi kuesioner sesuai waktu luangnya dan tidak tergesa-gesa. Pada saat kuesioner diberikan responden diberi penjelasan secara rinci mengenai tujuan pengisian kuesioner dan tata cara pengisiannya. Pada saat pengambilan kuesioner, peneliti menanyakan apabila ada pertanyaanpertanyaan tertentu yang kurang dipahami responden sehingga belum terisi.Hal ini dilakukan untuk memastikan tidak ada pertanyaan yang salah diinterpretasikan ataupun untuk menghindari adanya pertanyaan-pertanyaan tertentu yang tidak dijawab oleh responden karena ketidaktahuannya.

Setelah seluruh kuesioner terkumpul kemudian dilakukan pemeriksaan data, proses coding atau pemberian kode-kode tertentu untuk setiap variabel (pertanyaan) sebagai persiapan penyusunan data.Selanjutnya dilakukan data entry dan analisis data.

\subsection{Metode Analisis}

Untuk mengetahui karakteristik responden (variabel sosial-demografi dan variabel residensial), data diolah dengan menggunakan statistik deskriptif. Dari hasil analisis akan diperoleh gambaran karakteristik responden.

Selanjutnya dilakukan analisis faktor pada 28 variabel kualitas aspek arsitektur dan perencanaan kota. Dengan analisis faktor tersebut dapat diketahui pengelompokan variabelvariabel yang merupakan dimensi yang mendasari evaluasi masyarakat terhadap kualitas aspek arsitektur dan perencanaan kota pada lingkungan huniannya. Dari analisis faktor ini juga diperoleh berapa varians yang dapat dijelaskan oleh tiap kelompok variabel tersebut.

Selanjutnya pengaruh kualitas aspek arsitektur dan perencanaan kota (faktor-faktor aspek arsitektur dan perencanaan kota yang diperoleh dari analisis pada tahap satu) terhadap place attachment dianalisis dengan menggunakan analisis regresi (lihat Bonaiuto et al., 1999; Hair et al., 1998).

Secara keseluruhan analisis dalam penelitian ini dikerjakan dengan menggunakan program statistik SPSS (PASW 18). 


\section{Hasil dan Pembahasan}

Dalam penelitian ini, kepuasan berhuni terhadap aspek arsitektur dan perencanaan kota dikaji dengan mengukur evaluasi masyarakat terhadap lingkungan hunian mereka, yaitu indikator-indikator subyektif kualitas aspek arsitektur dan perencanaan kota suatu lingkungan hunian perkotaan. Berdasarkan kajian pustaka yang dilakukan, aspek arsitektur dan perencanaan kota merupakan salah satu aspek kualitas lingkungan hunian yang penting (Bonaito et al., 1999; Bonaiuto et al., 2004; Bonnes et el., 1997; Bonnes et al., 2004). Aspek arsitektur dan perencanaan kota tersebut dijabarkan dalam tiga variabel utama atau konsep, yaitu (1) ruang arsitektur dan perencanaan kota; (2) Organisasi aksesibilitas dan jaringan jalan; dan (3) Tata hijau.

Untuk mengetahui dimensi yang mendasari penilaian masyarakat terhadap ketiga variabel utama kualitas aspek arsitektur dan perencanaan kota pada lingkungan hunian tersebut maka dilakukan faktor analisis terhadap sub variable - sub variabel dalam setiap variabel utama tersebut. Selanjutnya dimensi-dimensi yang mendasari konsep tersebut digunakan sebagai variabel komposit untuk di analisis lebih lanjut untuk melihat hubungannya dengan pembentukan place attachment atau ikatan batin seseorang dengan lingkungan huniannya.

\subsection{Dimensi yang mendasari aspek arsitektur dan perencanaan kota}

\subsubsection{Ruang arsitektur dan perencanaan kota}

Untuk mengetahui dimensi yang mendasari evaluasi masyarakat terhadap kualitas ruang arsitektur dan perencanaan kota dilakukan analisis faktor terhadap ke-11 variabel dari konsep tersebut yang berdasarkan pilihan masyarakat melalui survei kualitatif. Dari analisis pendahuluan yang dilakukan, seluruh variabel memenuhi syarat untuk masuk dalam analisis. Dari analisis kelayakan terhadap 11 variabel tersebut diperoleh nilai determinant $>0.005$ yang merupakan syarat dilakukannya analisis faktor. Sedang nilai KMO masuk dalam kategori sangat baik, yaitu 0.851 (lihat Field, 2009), yang menunjukkan bahwa jumlah sampel sangat layak untuk analisis faktor. Sedangkan Bartlett's test menunjukkan nilai signifikansi $<0.001$ yang menunjukkan bahwa secara keseluruhan 11 variabel dari ruang arsitektur dan perencanaan kota tersebut sangat tepat untuk analisis faktor.

Principal axis factoring dengan rotasi oblique (direct oblimin) dilakukan terhadap ke 11 variabel ruang arsitektur dan perencanaan kota. Seperti yang dapat dilihat pada Tabel 3, hasil penelitian menunjukkan ada dua dimensi yang mendasari penilaian masyarakat terhadap kualitas ruang arsitektur dan perencanaan kota dari lingkungan hunian mereka. 
Tabel 3. Faktor-Faktor Kualitas Ruang Arsitektur dan Perencanaan Kota ${ }^{a}$

\begin{tabular}{|c|c|c|}
\hline & \multicolumn{2}{|c|}{ Component } \\
\hline & Faktor 1 & Faktor 2 \\
\hline Kepadatan Bangunan & .833 & \\
\hline Kualitas Bangunan & .832 & \\
\hline Ketinggian Bangunan & .797 & \\
\hline Ukuran Bangunan & .760 & \\
\hline Rencana Bangunan & .749 & \\
\hline Dinding Bangunan & .705 & \\
\hline Keindahan Bangunan & & .834 \\
\hline Bentuk dan Detail Bangunan & & .802 \\
\hline Warna Bangunan & & .796 \\
\hline Gaya Bangunan & & .707 \\
\hline $\begin{array}{l}\text { Proporsi Jumlah Bangunan dan } \\
\text { Ruang Terbuka }\end{array}$ & & .611 \\
\hline
\end{tabular}

Extraction Method: Principal Component Analysis.

Rotation Method: Oblimin with Kaiser Normalization.

a. Rotation converged in 4 iterations.

Dari Tabel 3 nampak bahwa Faktor 1 terdiri dari enam item yaitu kepadatan bangunan, kualitas bangunan, ketinggian bangunan, ukuran bangunan, rencana bangunan, dan dinding bangunan. Keenam item tersebut mengacu pada kualitas fisik bangunan dan lingkungan, maka diberi nama faktor Kualitas Fisik Bangunan. Faktor 2 terdiri dari lima item yaitu keindahan bangunan, bentuk dan detail bangunan, warna bangunan, gaya bangunan, dan proporsi jumlah bangunan dan ruang terbuka. Kelima item tersebut mengacu kepada keindahan bangunan dan lingkungan, maka untuk selanjutnya diberi nama faktor Estetika Bangunan dan Lingkungan. Hasil temuan pada penelitian ini menunjukkan bahwa ada dua dimensi atau faktor yang mendasari evaluasi masyarakat terhadap kualitas ruang arsitektur dan perencanaan kota pada lingkungan huniannya. Kedua dimensi tersebut menjelaskan $61,6 \%$ dari keberagaman yang ada di masyarakat, dengan kata lain, 61,6\% masyarakat memberikan penilaian yang sama terhadap kualitas ruang arsitektur dan perencanaan kota dari lingkungan huniannya, yang ditentukan oleh kedua dimensi tersebut.

Selanjutnya kedua dimensi yang mendasari evaluasi masyarakat terhadap kualitas ruang arsitektur dan perencanaan kota dari lingkungan hunian tersebut akan digunakan sebagai index atau variabel komposit dalam analisis berikutnya untuk melihat pengaruhnya terhadap terbentuknya place attachment (ikatan batin atau ikatan psikologis masyarakat terhadap lingkungan huniannya). 


\subsubsection{Organisasi aksesibilitas dan jaringan jalan}

Untuk mengetahui dimensi yang mendasari evaluasi masyarakat terhadap kualitas organisasi aksesibilitas dan jaringan jalan dilakukan analisis faktor terhadap ke-12 variabel dari organisasi aksesibilitas dan jaringan jalan.Sebelum dilakukan analisis faktor, maka dilakukan analisis kelayakan terhadap 12 variabel organisasi aksesibilitas dan jaringan jalan, dengan hasil nilai determinant $>0.005$ yang merupakan syarat dapat dilakukannya analisis faktor. Sedang nilai KMO masuk dalam kategori baik, yaitu 0.724 (lihat Field, 2009), yang menunjukkan bahwa jumlah sampel layak untuk analisis faktor. Sedangkan Bartlett's test menunjukkan nilai signifikansi $<0.001$ yang menunjukkan bahwa secara keseluruhan 12 variabel tersebut sangat tepat untuk analisis faktor.

Principal axis factoring dengan rotasi Oblimin dilakukan terhadap ke-12 variabel organisasi aksesibilitas dan jaringan jalan. Seperti yang dapat dilihat pada Tabel 4 hasil penelitian menunjukkan ada 4 dimensi atau faktor yang mendasari penilaian masyarakat terhadap kualitas organisasi aksesibilitas dan jaringan jalan pada lingkungan hunian mereka.

Faktor pertama terdiri dari 4 item, yaitu kemudahan sirkulasi, dimensi lebar jalan, ketersediaan ruang parkir, dan aksesibilitas untuk orang berkebutuhan khusus. Secara konsepsual faktor ini mengacu kepada fasilitas sirkulasi dan parkir, maka diberi nama faktor Sirkulasi dan Parkir.

Faktor kedua terdiri dari 3 item, yaitu koneksitas lingkungan hunian dengan tempattempat penting di kota (linkage internal), kemudahan menuju luar kota dari lingkungan hunian (linkage eksternal), dan kemudahan untuk mencapai pusat kota (linkage internal).Secara keseluruhan faktor kedua ini mengacu kepada hubungan antara tempat tinggal atau lingkungan hunian dengan tempat-tempat lain di luar kompleks lingkungan hunian. Oleh karena itu, faktor ketiga ini diberi label Hubungan Internal dan Eksternal.

Faktor yang ketiga terdiri dari 3 item.yaitu proporsi pengendara kendaraan bermotor dan pejalan kaki, ketersediaan fasilitas bagi pejalan kaki, dan lebar trotoar. Secara keseluruhan faktor ketiga ini mengacu kepada fasilitas pejalan kaki. Oleh karena itu faktor ketiga ini diberi label Fasilitas Pejalan Kaki.

Tabel 4. Faktor-Faktor Kualitas Organisasi Aksesibilitas dan Jaringan Jalan ${ }^{a}$

\begin{tabular}{|l|l|l|l|l|}
\hline \multicolumn{5}{|l|}{ Component } \\
\hline & Faktor 1 & Faktor 2 & Faktor 3 & Faktor 4 \\
\hline Kemudahan Sirkulasi & $\mathbf{. 8 8 8}$ & & & \\
\hline Lebar Jalan & $\mathbf{. 8 7 6}$ & & & \\
\hline Ketersediaan Parkir & $\mathbf{. 7 9 7}$ & & & \\
\hline $\begin{array}{l}\text { Kenyamanan aksesibilitas un- } \\
\text { tuk Orang Berkebutuhan Khu- } \\
\text { sus }\end{array}$ & $\mathbf{. 7 2 9}$ & & & \\
\hline $\begin{array}{l}\text { Koneksitas Lingkungan Hu- } \\
\text { nian dengan Tempat Penting di } \\
\text { Kota }\end{array}$ & & $\mathbf{. 9 0 7}$ & & \\
\hline
\end{tabular}




\begin{tabular}{|l|l|l|l|l|}
\hline \multicolumn{5}{|l|}{ Component } \\
\hline & Faktor 1 & Faktor 2 & Faktor 3 & Faktor 4 \\
\hline Kemudahan Sirkulasi & $\mathbf{. 8 8}$ & & & \\
\hline Lebar Jalan & $\mathbf{. 7 7 6}$ & & & \\
\hline Ketersediaan Parkir & $\mathbf{. 7 9 7}$ & & & \\
\hline $\begin{array}{l}\text { Kemudahan untuk Menuju } \\
\text { Luar Kota dari Lingkungan } \\
\text { Hunian }\end{array}$ & & $\mathbf{. 8 7 7}$ & & \\
\hline $\begin{array}{l}\text { Kemudahan untuk Mencapai } \\
\text { Pusat Kota }\end{array}$ & & $\mathbf{. 8 0 8}$ & & \\
\hline $\begin{array}{l}\text { Proporsi Pengendara dan Pe- } \\
\text { jalan Kaki }\end{array}$ & & & $\mathbf{. 8 3 5}$ & \\
$\begin{array}{l}\text { Ketersediaan Fasilitas Bagi } \\
\text { Pejalan Kaki }\end{array}$ & & & $\mathbf{. 7 8 8}$ & \\
\hline $\begin{array}{l}\text { Lebar Trotoar } \\
\text { Jaringan Jalan Membuat Orang } \\
\text { Sering Berputar-putar }\end{array}$ & & & $\mathbf{. 7 2 1}$ & \\
\hline $\begin{array}{l}\text { Keberadaan Jalan Raya Men- } \\
\text { gurangi Kenyamanan Berhuni }\end{array}$ & & & & \\
\hline $\begin{array}{l}\text { Extraction Method: Principal Component Analysis. } \\
\text { Rotation Method: Oblimin with Kaiser Normalization. } \\
\text { a. Rotation converged in 5 iterations. }\end{array}$ & & \\
\hline
\end{tabular}

Sedangkan faktor keempat hanya terdiri dari 2 item, yaitu sistem jaringan jalan dan dampak keberadaan jalan raya terhadap kenyamanan berhuni. Faktor keempat ini mengacu pada organisasi jaringan jalan maka diberi label faktor Organisasi Jaringan Jalan.

Secara keseluruhan keempat faktor tersebut menjelaskan 71,3\% dari keberagaman yang ada di masyarakat. Dengan kata lain $71,3 \%$ masyarakat memiliki penilaian yang relatif sama terhadap organisasi aksesibilitas dan jaringan jalan yang ditentukan oleh keempat dimensi atau faktor tersebut.

\subsubsection{Tata Hijau}

Untuk mengetahui dimensi yang mendasari evaluasi masyarakat terhadap kualitas tata hijau dilakukan analisis faktor terhadap 5 variabel tata hijau yang diperoleh dari pilihan masyarakat melalui survei kualitatif. Sebelum dilakukan analisis faktor, maka dilakukan analisis kelayakan terhadap 5 variabel tata hijau, dengan hasil nilai determinant $>0.005$ yang merupakan syarat dapat dilakukannya analisis faktor. Sedang nilai KMO masuk dalam kategori cukup baik, yaitu 0.668 (lihat Field, 2009), yang menunjukkan bahwa jumlah sampel layak untuk analisis faktor. Sedang-kan Bartlett's test menunjukkan nilai signifikansi $<0.001$ yang menunjukkan bahwa secara keseluruhan 5 variabel tersebut sangat tepat untuk analisis faktor. 
Dalam penelitian ini ditemukan bahwa ada 2 dimensi yang mendasari penilaian masyarakat terhadap kualitas tata hijau di lingkungan hunian mereka (hasil analisis kelayakan untuk analisis faktor dan hasil analisis statistik dapat dilihat pada lampiran).

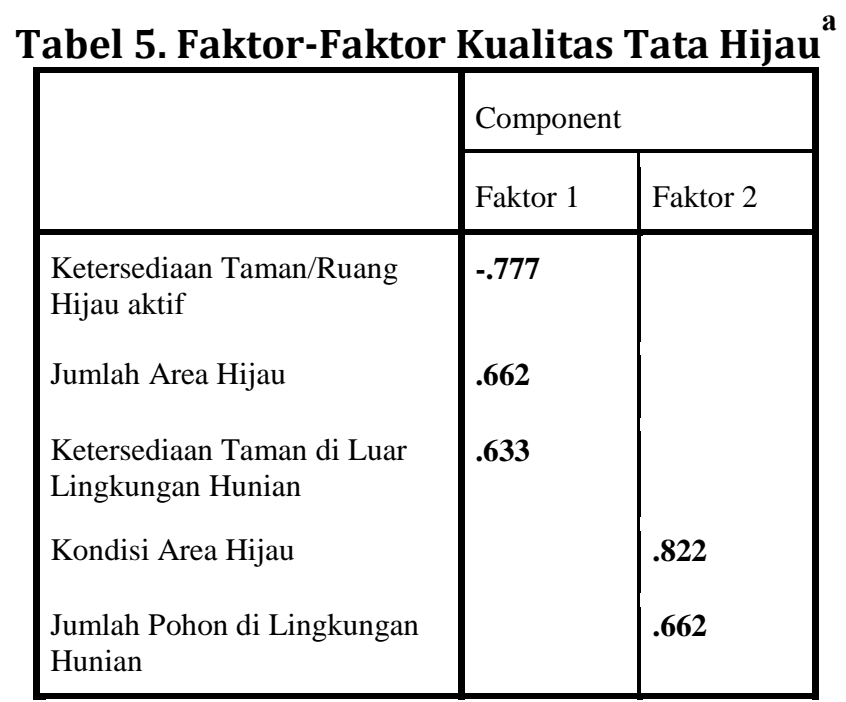

Extraction Method: Principal Component Analysis.

Rotation Method: Oblimin with Kaiser Normalization.

a. Rotation converged in 10 iterations.

Faktor kualitas tata hijau yang pertama terdiri dari 3 item, yaitu keberadaan ruang hijau aktif, jumlah area hijau, dan ketersediaan taman di wilayah kota. Ketiga item tersebut mengacu kepada keberadaan/ketersediaan ruang terbuka hijau. Oleh karena itu, maka faktor pertama ini diberi label Ketersediaan Ruang Terbuka Hijau.

Faktor kualitas tata hijau kedua hanya terdiri dari 2 item, yaitu kondisi area hijau dan jumlah pohon di lingkungan hunian.Kedua item tersebut mengacu kepada kualitas area hijau yang memadai. Oleh karena itu faktor kedua diberi label Kualitas Area Hijau.

Dari hasil penelitian terungkap bahwa total varian untuk penilaian masyarakat terhadap kualitas tata hijau lingkungan hunian adalah 58\%. Hasil penelitian ini menunjukkan bahwa setidaknya 58\% masyarakat menilai kualitas tata hijau lingkungan dengan penilaian yang relatif sama, yaitu ditentukan oleh kedua dimensi atau faktor tersebut.

\subsection{Pengaruh aspek arsitektur dan perencanaan kota terhadap terbentuknya ikatan batin dengan suatu tempat (place attachment)}

Untuk mengetahui pengaruh aspek arsitektur dan perencanaan kota terhadap terbentuknyaplace attachment dilakukan analisis regresi berganda. Analisis regresi dilakukan dengan memperlakukan 3 variabel utama aspek arsitektur dan perencanaan kota, yaitu (1) ruang arsitektur dan perencanaan kota (yang terdiri dari 11 variabel); (2) organisasi aksesibilitas dan jaringan jalan (yang terdiri dari 12 variabel); dan (3) tata hijau (yang terdiri dari 5 variabel) sebagai variabel bebas, dan place attachment sebagai variabel terikat. Mengingat bahwa variabel-variabel tersebut telah di reduksi menjadi beberapa faktor, yaitu ruang arsitektur dan perencanaan kota (2 faktor), organisasi aksesibilitas dan jaringan jalan (4 faktor), dan tata hijau (2 faktor).maka analisis regresi dilakukan terhadap factor score dari dimensi- 
dimensi yang telah terbentuk tersebut. Melalui proses regresi secara bertahap ini, akan dapat diketahui faktor-faktor kualitas ruang arsitektur dan perencanaan kota; organisasi aksesibilitas dan jaringan jalan; serta tata hijau yang signifikan mempe-ngaruhi terbentuknya place attachment.

Untuk setiap faktor, indikator yang digunakan dalam model regresi adalah yang memiliki nilai koefisien $\beta$ yang signifikan sebagai prediktor $(\mathrm{p}<.05)$ (lihat Hair et al, 1999; Field, 2009).Dari hasil analisis regresi dengan place attachment sebagai variabel terikat (dependent variabel) dan variabel arsitektur dan perencanaan kota sebagai variabel bebas (independent variabel), maka ditemukan bahwa hubungan yang terbentuk adalah signifikan dengan $\mathrm{p}<.001$. Maksudnya, dari hasil analisis tersebut diketahui bahwa variabel ruang arsitektur dan perencanaan kota; organisasi aksesibilitas dan jaringan jalan; serta tata hijau mempengaruhi terbentuknya place attachment (ikatan batin/psikologis antara masyarakat dengan lingkungan huniannya). Lebih jauh penelitian ini menemukan bahwa dari ketiga faktor tersebut, variabel ruang arsitektur dan perencanaan kota memberikan pengaruh yang terbesar terhadapterbentuknyaplace attachment, yaitu 19,1\% (lihat nilai Adjusted R Square pada Tabel 6). Variabel organisasi aksesibilitas dan jaringan jalan serta tata hijau memberikan kontribusi 8,2\% sebagai prediktor place attachment. Dari ketiga variabel tersebut, organisasi aksesibilitas dan jaringan jalan memberikan pengaruh yang terkecil terhadap terbentuknyaplace attachment dibandingkan dengan dua variabel yang lain dari aspek arsitektur dan perencanaan kota.

Table 6 Model Summary 1 (Aspek Arsitektur dan Perencanaan Kota)

\begin{tabular}{|c|c|c|c|c|c|}
\hline Model & $\mathrm{R}$ & R Square & $\begin{array}{l}\text { Adjusted R } \\
\text { Square }\end{array}$ & $\begin{array}{l}\text { Std. Error of the } \\
\text { Estimate }\end{array}$ & Durbin-Watson \\
\hline 1 & $.447^{\mathrm{a}}$ & .200 & .191 & .89926992 & \\
\hline 2 & $.492^{\mathrm{b}}$ & .242 & .218 & .88433735 & \\
\hline 3 & $.546^{\mathrm{c}}$ & .299 & .272 & .85322787 & 1.382 \\
\hline \multicolumn{6}{|c|}{ a. Predictors: (Constant), Kualitas Fisik Bangunan, Estetika Bangunan dan Lingkungan } \\
\hline \multicolumn{6}{|c|}{$\begin{array}{l}\text { b. Predictors: (Constant), Kualitas Fisik Bangunan, Estetika Bangunan dan Lingkungan, Fasilitas Pejalan Kaki, } \\
\text { Hubungan Internal dan Eksternal, Organisasi Jaringan Jalan, Sirkulasi dan Parkir }\end{array}$} \\
\hline \multicolumn{6}{|c|}{$\begin{array}{l}\text { c. Predictors: (Constant), Kualitas Fisik Bangunan, Estetika Bangunan dan Lingkungan, Fasilitas Pejalan Kaki, } \\
\text { Hubungan Internal dan Eksternal, Organisasi Jaringan Jalan, Sirkulasi dan Parkir, Fasilitas Ruang Terbuka Hijau }\end{array}$} \\
\hline
\end{tabular}

Hasil analisis ANOVA menunjukkan bahwa model yang terbentuk antara ketiga prediktor dari aspek arsitektur dan perencanaan kota dengan place attachment adalah signifikan ( $\mathrm{p}<0.001$ ), yang berarti bahwa ketiga variabel dari aspek arsitektur dan perencanaan kota tersebut secara signifikan mempengaruhi terbentuknyaplace attachment.

Secara keseluruhan aspek arsitektur dan perencanaan kota meliputi 8 faktor, yaitu: (1) Kualitas Fisik Bangunan; (2) Estetika Bangunan dan Lingkungan; (3) Sirkulasi dan Parkir; (4) Hubungan Internal dan Eksternal; (5) Fasilitas Pejalan Kaki; (6) Organisasi Jaringan Jalan; (7) Ketersediaan Ruang Terbuka Hijau; (8) Kualitas Area Hijau. Namun demikian, hasil penelitian menunjukkan bahwa ada 4 faktor dari aspek arsitektur dan perencanaan ko- 
ta yang tidak signifikan mempengaruhi terbentuknyaplace attachment, yaitu Kualitas Fisik Bangunan, Sirkulasi dan Parkir, Hubungan Internal dan Eksternal, dan Kualitas Area Hijau. Hal ini berarti bahwa hanya ada 4 faktor yang signifikan mempengaruhi terbentuknyaplace attachment, yang mewakili ketiga variabel utama aspek arsitektur dan perencanaan kota(diurutkan dari yang paling besar pengaruhnya) yaituEstetika Bangunan dan Lingkungan $(p<0.005)$, Ketersediaan Ruang Terbuka Hijau $(p<0.005)$, Organisasi Jaringan Jalan $(p<$ $0.01)$ dan Fasilitas Pejalan Kaki $(p<0.05)$. Secara keseluruhan, hasil penelitian menunjukkan bahwa terbentuknya place attachment 27,2\% ditentukan oleh keempat faktor arsitektur dan perencanaan kota yang merupakan faktor fisik-spasial tersebut.

Secara singkat hasil penelitian menunjukkan bahwa arsitektur dan perencanaan kota merupakan aspek utama kualitas suatu lingkungan hunian yang mempengaruhi terbentuknya place attachment (ikatan batin atau kelekatan psikologis antara individu dengan suatu tempat yang dalam konteks penelitian ini adalah lingkungan huniannya). Place attachment itu sendiri merupakan isu penting yang telah menarik beberapa peneliti (seperti Fried, 1982; Giuliani, 1991; Altman \& Low, 1992; Giuliani \& Feldman, 1993; Feldman, 1996; Twigger-Ross \& Uzzell, 1996; Bonaiuto et al., 1999; Bonaiuto et al., 2004; Bonnes et al., 1997; Bonnes et al., 2004) untuk dapat memahami cara masyarakat menetapkan ikatan afektif atau rasa cinta terhadap tempat-tempat tertentu dalam lingkungan hunian mereka, yang dapat menjadi bagian dari identitas suatu tempat (Ernawati, 2005; Proshansky et al., 1983; Low \& Altman, 1992).

Secara keseluruhan dapat disimpulkan bahwa persepsi masyarakat terhadap kualitas aspek arsitektur dan perencanaan kota yang berpengaruh terhadap terbentuknya place attachment meliputi faktor Estetika Bangunan dan Lingkungan, Fasilitas Pejalan Kaki, Organisasi Jaringan Jalan, dan Ketersediaan Ruang Terbuka Hijau. Estetika Bangunan dan Lingkungan memberikan kepuasan secara psikologis bagi masyarakat yang membuat mereka mencintai lingkungan huniannya, yang memberi dampak positif bagi kelekatan batin masyarakat terhadap tempat tinggalnya.Fasiltias Pejalan Kaki juga merupakan faktor yang menentukan place attachment. Semakin baik ketersediaan dan kualitas fasilitas bagi para pejalan kaki di suatu lingkungan hunian akan memberikan implikasi pada meningkatnya keterikatan masyarakat dengan lingkungan huniannya (place attachment). Hal ini berarti masyarakat senang dan betah tinggal di suatu lingkungan hunian yang "akrab", yang dapat mereka jelajahi dengan berjalan kaki. Semakin baik kualitas fasilitas pejalan kaki akan berpengaruh pada semakin kuatnya ikatan batin dan rasa cinta masyarakat terhadap lingkungan huniannya. Organisasi Jaringan Jalan yang memberi implikasi pada kemudahan aksesibilitas dan legibilitas suatu kawasan juga memberi pengaruh pada terbentuknya place attachment.Sebaliknya, Organisasi Jaringan Jalan yang tidak beraturan atau ruwet memberi implikasi tidak disukainya lingkungan tersebut oleh para penghuninya.Ketersediaan Ruang Terbuka Hijau juga ditemukan sebagai salah satu faktor yang besar kontribusinya terhadap pembentukan place attachment.Boleh jadi seseorang tidak menyukai tempat tinggalnya akibat gersangnya lingkungan hunian dan terbatasnya ruang terbuka hijau yang ada.Peningkatan ketersediaan ruang terbuka hijau dapat meningkatkan rasa kecintaan (ikatan batin) masyarakat terhadap lingkungan hunian mereka tersebut.Sebaliknya, dalam kondisi perubahan merupakan penurunan kualitas dan kuantitas, maka dapat mengakibatkan penuruan pada nilai place attachment.

\section{Kesimpulan}


1. Terdapat hubungan yang signifikan antara persepsi masyarakat terhadap kualitas aspek arsitektur dan perencanaan kota dengan place attachment (ikatan batin/ikatan psikologis antara masyarakat dengan lingkungan huniannya).

2. Terdapat 4 faktor dari aspek arsitektur dan perencanaan kota yang berpengaruh langsung pada terbentuknya place attachmen, yaitu faktor Estetika Bangunan dan Lingkungan, Fasilitas Pejalan Kaki, Organisasi Jaringan Jalan, dan Ketersediaan Ruang Terbuka HIjau.

3. Secara keseluruhan, keempat faktor dari aspek arsitektur dan perencanaan kota tersebut memberikan kontribusi sebesar $27,2 \%$ bagi terbentuknya place attachment. Masih ada 72,8\% faktor lain yang menentukan terbentuknya place attachment yang tidak termasuk dalam penelitian ini. Oleh karena itu perlu dilakukan penelitian selanjutnya yang dapat mengungkapkan faktor-faktor pembentuk place attachment yang lain yang belum termasuk dalam penelitian ini.

\section{Ucapan Terima Kasih}

Penulis mengucapkan terimakasih kepada Direktorat Jenderal Pendidikan Tinggi, Kementerian Pendidikan dan Kebudayaan Nasional yang telah membiayai penelitian ini melalui DIPA Universitas Brawijaya Hibah Penelitian Fundamental.

\section{Daftar Pustaka}

Altman, I. \& Low, S. (Eds) (1992). Place attachment, Human Behaviour and Environment, Vol. 12. New York: Plenum Press.

Andriaanse, C. (2007). Measuring Residential Satisfaction: a Residential Environmental Satisfaction Scale (RESS). Journal of Housing and the Built Environment, 22 (3), pp. 287304.

Bonaiuto, M., Aiello, A., Perugini, M., Bonnes, M. \& Ercolani, A. P. (1999).Multidimensional perception of residential environment quality and neighbourhood attachment in the urban environment.Journal of Environmental Psychologi, 19 (4), pp. 331-352.

Bonaiuto, M., Fornara, F. \& Bonnes, M. (2004). Scales on Perceived Urban Residential Quality Indicators.In B. Martens \& A. G. Keul (Eds.), Evaluation in Progress - Strategies for Environmental Research and Implementation.IAPS 18 Conference Proceedings.

Bonnes, M., Bonaiuto, M., Aiello, A., Perugin, M. \& Ercolani, A. P. (1997). A transactional Perspective on Residential Satisfaction.In C. Despres \& D. Piche (Eds.). Housing Surveys: Advances in Theory and Methods. Quebec, Canada: CRAD Universite Laval, pp. 75-99.

Bonnes, M., Carrus, G. \& Passafaro, P. (2004). Attitudes Towards Urban Green Spaces, Perceived Residential Quality and Neighbourhood Attachment. In B. Martens \& A. G. Keul (Eds.), Evaluation in Progress - Strategies for Environmental Research and Implementation.IAPS 18 Conference Proceedings.

Ernawati, J. (1992). Studi Pendekatan Penanganan Permukiman di Kawasan Bersejarah Kota yang Merupakan Aset Wisata. Bandung: ITB.

Ernawati, J. (2005). Impressions and Cognitive Evaluations of an Historic District by Tourists and the Local Community. Sydney: The University of Sydney.

Ernawati, J. \& Mustikawati, T. (2010).Model Teoritik Hubungan Kepuasan Berhuni Dengan Place attachment.Malang: LPPM UB.

Field, A. (2009). Discovering Statistics Using SPSS for Windows. London: SAGE Publications. 
Fried, M. (1982). Residential Attachment: Sources of Residential and Community Satisfaction. Journal of Social Issues, 38, 107-119.

Giuliani, M. V. (1991). Towards an Analysis of Mental Representations of Attachment to the Home.Journal of Architectural and Planning Research, 8, pp. 133-146.

Giuliani, M. V. \& Feldman, R. M. (1993). Place attachment in a Developmental and Cultural Context. Journal of Environmental Psychology, 13, 267-274.

Hair, J. F., Anderson, R. E., Tatham, R. L. \& Black, W. C. (1998).Multivariate Data Analysis. New Jersey: Prentice Hall.

Hoyle, R. H., Harris, M. J. \& Judd, C. M. (2002).Research Methods In Social Relations. Wadsworth: Thomson Learning.

Huck, S. W. (2000).Reading Statistics and Research. New York: Longman.

Kwanda, T., Rahardjo, J. \& Wardani, M. K. (2001). Analisis Kepuasan Penghuni Perumahan Sederhana di Denpasar Berdasarkan Faktor Lokasi, Prasarana, Sarana, Kualitas Bangunan, Desain dan Harga. Dimensi Teknik Arsitektur, 29 (2).

Low, S. \& Altman, I. (1992).Place attachment: A Conceptual Inquiry.In I. Altman \& S. Low (Eds.). Place attachment, Human Behaviour and Environment, Vol. 12. New York: Plenum Press, pp. 1-12.

Prasojo, W. \& Frida, N. (2014).Analisis tingkat kepuasan penghuni pada hunian rumah susun ditinjau terhadap kualitas bangunan di wilayah Surabaya.Rekayasa Teknik Sipil, 3 (1). pp. 54-62.

Proshansky, H., Fabian, A. K. \& Kaminoff, R. (1983). Place Identity: Physical World Socialization of the Self. Journal of Environmental Psychology, 3, 57-83.

Rahardjo, J. \& Wibowo, B. R. (2003).Analisis Kepuasan Penghuni Rumah Sederhana Tipe 36 di Kawasan Sidoarjo Berdasarkan Faktor Kualitas Bangunan, Lokasi, Desain, Sarana \& Prasarana.Dimensi Teknik Arsitektur, Vol. 31 (2).

Sundstrom, E., Bell, P.A., Busby, P.L. \& Asmus, C. (1996). Environmental Psychology 19891994. Annual review of Psychology, 47, 485-512.

Tognoli, J. (1987). Residential Environments.In D. Stokols \& I. Altman (Eds.), Handbook of Environmental Psychology, Vol. 1. New York: Wiley, pp. 655-690.

Twigger-Ross, C. L. \& Uzzel, D. L. (1996).Place and Identity Processes.Journal of Environmental Psychology, 16, 205-220. 